\title{
Glucose modulation of ATP-sensitive K-currents in wild-type, homozygous and heterozygous glucokinase knock-out mice
}

\author{
H.Sakura ${ }^{1}$, S. J.H. Ashcroft ${ }^{2}$, Y. Terauchi ${ }^{3}$, T. Kadowaki ${ }^{3}$, F.M. Ashcroft ${ }^{1}$ \\ ${ }^{1}$ University Laboratory of Physiology, Oxford, UK \\ ${ }^{2}$ Nuffield Department of Clinical Biochemistry, John Radcliffe Hospital, Headington, Oxford, UK \\ ${ }^{3}$ Third Department of Internal Medicine, Faculty of Medicine, University of Tokyo, Tokyo, Japan
}

\begin{abstract}
Summary One type of maturity-onset diabetes of the young (MODY2) is caused by mutations in the glucokinase gene, a key glycolytic enzyme in the beta cell and liver. Glucose fails to stimulate insulin secretion in mice in which the glucokinase gene has been selectively knocked out in the beta cell. We tested the hypothesis that this effect results from defective metabolic regulation of beta cell ATP-sensitive potassium $\left(\mathrm{K}_{\mathrm{ATP}}\right)$ channels. Glucose had little effect on $\mathrm{K}_{\text {ATP }}$ currents in homozygous (-/-) mice but inhibited $\mathrm{K}_{\text {ATP }}$ currents in wild-type $(+/+)$ and heterozygous $(+/-)$ mice with $\mathrm{EC}_{50}$ of $3.2 \mathrm{mM}$ and $5.5 \mathrm{mM}$, respectively, in newborn animals, and of $4.7 \mathrm{mM}$ and $9.9 \mathrm{mM}$, respectively, in 1.5-year-old mice. Glucose
\end{abstract}

(20 $\mathrm{mmol} / \mathrm{l})$ did not affect the resting membrane potential of -/- beta cells but depolarised wild-type and $+/$ - beta cells and induced electrical activity. In contrast, $20 \mathrm{mmol} / \mathrm{l} \mathrm{ketoisocaproic} \mathrm{acid} \mathrm{or} 0.5 \mathrm{mmol} /$ 1 tolbutamide depolarised all three types of beta-cell. These results support the idea that defective glycolytic metabolism, produced by a loss (-/- mice) or reduction $(+/-$ mice) of glucokinase activity, leads to defective $\mathrm{K}_{\text {ATP }}$ channel regulation and thereby to the selective loss, or reduction, of glucose-induced insulin secretion. [Diabetologia (1998) 41: 654-659]

Keywords ATP-sensitive K-current, glucokinase, beta cell, insulin secretion, MODY.
It is well established that glucose and other nutrient secretagogues must be metabolised by beta cells in order to stimulate insulin secretion [1]. Glucose metabolism results in the closure of ATP-sensitive potassium $\left(\mathrm{K}_{\text {ATP }}\right)$ channels in the beta-cell plasma membrane [2]. This causes beta-cell depolarization, activation of voltage-dependent $\mathrm{Ca}^{2+}$ channels, enhanced $\mathrm{Ca}^{2+}$ influx and thereby induces insulin secretion. The first enzyme of glucose metabolism is glucokinase, which catalyses the phosphorylation of glucose to glucose-6-phosphate. The activity of this

Received: 22 October 1997 and in revised form 9 January 1998

Corresponding author: Professor F.M. Ashcroft, University Laboratory of Physiology, Parks Road, Oxford OX1 3PT, UK Abbreviations: MODY, Maturity-onset diabetes of the young; $\mathrm{K}_{\text {ATP }}$ channel, ATP-sensitive K-channel; KIC, ketoisocaproic acid; ATP, adenosine-5 '-triphosphate; PCR, polymerase chain reaction; HEPES, N-2-hydroxyethylpiperazine- $\mathrm{N}^{\prime}$-2ethanesulphonic acid. enzyme is rate-limiting for glucose metabolism and determines the glucose-dependence of many processes in the beta cell [3, 4]. Glucokinase has therefore been considered as an essential 'glucose-sensor' molecule. This theory is supported by the fact that mutations in the human glucokinase gene cause a form of maturity-onset diabetes of the young (MODY2) [5-7]. In French families, around 50\% of all MODY patients suffer from MODY2 and carry mutations in the glucokinase gene. Glucokinase is expressed not only in the beta cells but also in the liver [8]. This raises the possibility that impaired liver function might also be involved in the development of diabetes in MODY2 patients [9-11]. Recent experiments however, have shown that the selective destruction of glucokinase in beta cells is sufficient to cause diabetes, since a beta-cell specific glucokinase knockout mice developed the disease [12-14].

The clinical characteristics of the heterozygous glucokinase knockout mice were very similar to those 
of MODY2 patients, who are also all heterozygous for the glucokinase mutation. In contrast, the homozygous knockout (-/-) mice developed very severe diabetes within 1 day of birth [12]. The fetal development of mutant mice was normal, even in homozygous animals, indicating that glucokinase, and probably insulin, is not essential during the fetal period [12]. Islets isolated from mutant mice after birth, however, showed reduced (heterozygous) or almost no (homozygous) insulin secretion in response to glucose. In this study, we have examined the reason for this reduced insulin secretory response to glucose in more detail. In particular, we have explored the possibility that it results from a reduced glucose-sensitivity of the $\mathrm{K}_{\mathrm{ATP}}$ channel.

\section{Materials and methods}

Animals. The glucokinase knock-out mice used in these experiments were established in Japan $[12,13]$ and imported to the United Kingdom. The characteristics of the mouse colony maintained in our laboratory were the same as those described in the original paper [12]. Homozygous mutant mice developed diabetes immediately after birth and died within one week. The fasting blood glucose of 3 -week-old mice was $4.5 \pm 0.5 \mathrm{mmol} / \mathrm{l}(n=6)$ for wild-type and $7.9 \pm 0.4 \mathrm{mmol} / \mathrm{l}$ $(n=9)$ for heterozygous animals. The genotypes of all mice used in the experiments described here were checked by the urine sugar concentration and confirmed by polymerase chain reaction (PCR), as described previously [12]. In this study, we principally used neonatal mice, aged 1-3 days. We also studied wild-type and heterozygous mice at $1 \frac{1}{2}$ years of age: these are defined as old mice.

Isolation of islets and beta cells. Mice were killed by cervical dislocation. The pancreas was removed, cut into pieces and placed in Hank's solution containing collagenase (in $\mathrm{mmol} / \mathrm{l}$ ): $137 \mathrm{NaCl}, 1.2 \mathrm{NaHPO}_{4}, 5.6 \mathrm{KCl}, 1.2 \mathrm{CaCl}_{2}, 10 \mathrm{~N}$-2-hydroxyethylpiperazine-N'-2ethanesulphonic acid (HEPES) ( $\mathrm{pH} 7.4$ with $\mathrm{NaOH}$ ), $4.2 \mathrm{NaHCO}_{3}, 2.8$ glucose plus $5 \mathrm{mg} / \mathrm{ml}$ bovine serum albumin and $2.5 \mathrm{mg} / \mathrm{ml}$ collagenase. The pancreas was digested by hand-shaking in this solution for $8 \mathrm{~min}$ and islets were then removed by hand. Isolated islets were dispersed into single cells by trypsin digestion for $10 \mathrm{~min}$ at $37^{\circ} \mathrm{C}$ in a solution containing (mmol/l): $137 \mathrm{NaCl}, 1.2 \mathrm{NaHPO}_{4}, 5.6 \mathrm{KCl}, 1$ EGTA, 10 HEPES (pH 7.4 with $\mathrm{NaOH}$ ), 4.2 $\mathrm{NaHCO}_{3}, 2.8$ glucose and $0.1 \times$ trypsin solution (SIGMA Poole, UK). Beta cells were maintained in RPMI tissue culture medium containing $11 \mathrm{mmol} / \mathrm{l}$ glucose supplemented with $10 \%$ fetal calf serum. Cells were used 1-4 days after the isolation.

Electrophysiology. Patch pipettes were pulled from borosilicate glass capillaries, coated with Sylgard close to their tips and fire-polished immediately before use. They had resistances of 2-5 $\mathrm{M} \Omega$ when filled with pipette solution. Membrane potentials and whole-cell currents were recorded using an EPC-7 patch-clamp amplifier (List Electronic, Darmstadt, Germany) and stored on digital audio tape for later analysis. The zero current potential of the pipette was adjusted with the pipette in the bath before establishment of the seal and no corrections have been made for liquid junction potentials. The majority of experiments were carried out using the perforated-patch configuration, which retains cell metabolism in- tact [15]. Currents flowing through $\mathrm{K}_{\mathrm{ATP}}$ channels were monitored using alternate $\pm 20 \mathrm{mV}$ pulses $( \pm 10 \mathrm{mV}$ for standard whole-cell recordings) of 200 min duration which were applied at frequency of $0.5 \mathrm{~Hz}$ from a holding potential of $-70 \mathrm{mV}$. Membrane potentials were measured as the potential of the pipette when no current was applied (in current-clamp mode).

For perforated-patch experiments, the pipette solution contained (mmol/l): $70 \mathrm{~K}_{2} \mathrm{SO}_{4}, 10 \mathrm{NaCl}, 10 \mathrm{KCl}, 2 \mathrm{MgCl}_{2}, 10 \mathrm{HE}$ PES (pH 7.2 with $\mathrm{KOH}$ ), 40 sucrose, and $0.24 \mathrm{mg} / \mathrm{ml}$ amphotericin B. For standard whole-cell recordings, the pipette was filled with (mmol/l): $107 \mathrm{KCl}, 1 \mathrm{CaCl}_{2}, 2 \mathrm{MgCl}_{2}, 11$ EGTA, 10 HEPES ( $\mathrm{pH} 7.2$ with $\mathrm{KOH}$ ), and $0.3 \mathrm{~K}_{2} \mathrm{ATP}$. The standard external solution consisted of (mmol/l): $138 \mathrm{NaCl}, 5.6 \mathrm{KCl}, 1.2$ $\mathrm{MgCl}_{2}, 2.6 \mathrm{CaCl}_{2}$ and 5 HEPES (pH 7.4 with $\mathrm{NaOH}$ ). D-glucose and $\alpha$-ketoisocaproic acid (KIC) were added to the standard external solution as indicated. Tolbutamide was made up as a 0.5 mol stock solution in dimethyl sulphoxide (DMSO), and diluted as required. All experiments were carried out at room temperature $\left(22-24^{\circ} \mathrm{C}\right)$.

Statistical analysis. Currents were filtered at $10 \mathrm{kHz}$, digitised at $5 \mathrm{kHz}$ using a Digidata 1200 Interface and subsequently analysed using pClamp software (Axon Instruments, Burlingame, USA). Dose-response relations for glucose inhibition of $\mathrm{K}_{\text {ATP }}$ currents were obtained by alternating test solutions with control (glucose-free) solution. The control conductance was taken as the mean of that obtained in the control solution before and after application of the test glucose concentration. The conductance $(I)$ is plotted as a fraction of that obtained in the control solution $\left(I_{\mathrm{c}}\right) \cdot \mathrm{EC}_{50}$ values were obtained from curves which were fit through the data points by eye.

Data are given as means \pm SEM. The symbols in the figures indicate the mean and the vertical bars indicate SEM (where this is larger than the symbol). Statistical significance was evaluated by a two-tailed student's $t$-test.

\section{Results}

Appearance. Neonatal mice islets were smaller and more translucent than those of adult mice, but there was no obvious visible difference between wild-type $(+/+)$, heterozygote $(+/-)$ and homozygote $(-/-)$ islets. More than $90 \%$ of single beta cells of all genotypes survived for up to 1 week in culture (as assessed by trypan blue exclusion).

Membrane potential recordings. We first compared the effect of secretagogues on the membrane potential of beta cells isolated from neonatal wild-type and homozygous (-/-) mice. In $3 \mathrm{mmol} / \mathrm{l}$ glucose, the resting potential was not significantly different, being $-67.8 \pm 2.5 \mathrm{mV}(n=4)$ for wild-type beta cells and $-67.3 \pm 1.3 \mathrm{mV}(n=4)$ for homozygous $(-/-)$ beta cells. Application of $20 \mathrm{mmol} / \mathrm{l}$ glucose, $20 \mathrm{mmol} / \mathrm{l}$ $\mathrm{KIC}$ or $0.5 \mathrm{mmol} / \mathrm{l}$ tolbutamide to wild-type beta cells induced membrane depolarization and triggered electrical activity (Fig. 1 a and 3 other cells). By contrast, $20 \mathrm{mmol} / \mathrm{l}$ glucose failed to induce membrane depolarization in homozygous (-/-) beta cells, although the response to KIC or tolbutamide was very 

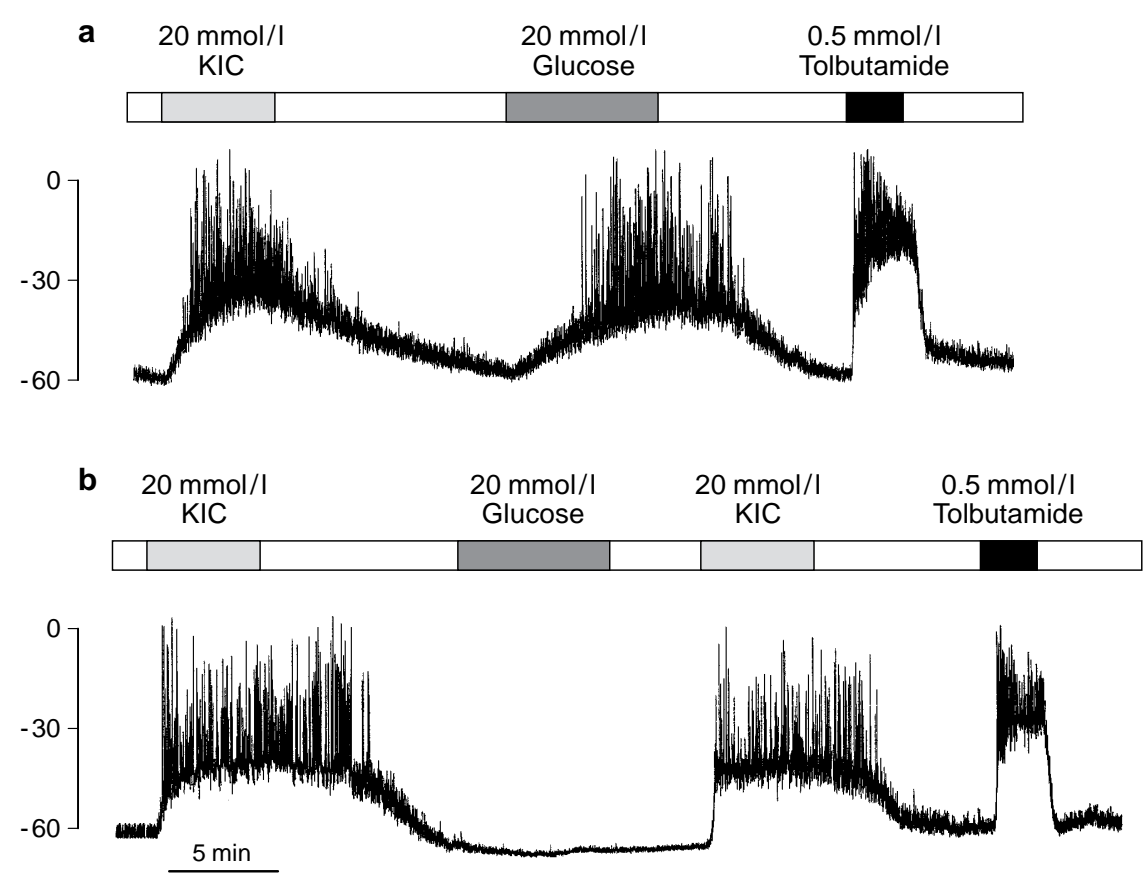

Fig. 1. Effect of KIC $(20 \mathrm{mmol} / \mathrm{l})$, glucose $(20 \mathrm{mmol} / \mathrm{l})$ and tolbutamide $(0.5 \mathrm{mmol} / \mathrm{l})$ on the membrane potential of a neonatal wild-type (a) or homozygous (-/-) beta cell (b). The control solution (indicated by the white bar) contained $3 \mathrm{mmol} / \mathrm{l}$ glucose. Current-clamp recordings using the perforated-patch configuration. The results are representative of 4 experiments in each case

similar to those found for wild-type beta cells (Fig. 1 b and 3 other cells).

Effect of secretagogues on $K_{A T P}$ currents of neonatal mouse beta cells. As shown in Fig. 2 a, whole-cell $\mathrm{K}_{\mathrm{ATP}}$ currents in wild-type beta cells were almost completely blocked by $10 \mathrm{mmol} / \mathrm{l}$ glucose, $20 \mathrm{mmol} / \mathrm{l}$ $\mathrm{KIC}$ or $0.5 \mathrm{mmol} / \mathrm{l}$ tolbutamide. This inhibition accounts for the ability of these secretagogues to induce membrane depolarization. The mean latency to $5 \%$ inhibition of the $\mathrm{K}_{\mathrm{ATP}}$ current was $83 \pm 7 \mathrm{~s}(n=10)$ for $10 \mathrm{mmol} / \mathrm{l}$ glucose, $41 \pm 7 \mathrm{~s}(n=8)$ for $20 \mathrm{mmol} / 1$ KIC and $17 \pm 3 \mathrm{~s}(n=8)$ for $0.5 \mathrm{mmol} / \mathrm{l}$ tolbutamide. The faster onset of the tolbutamide block may reflect the fact that the drug inhibits the $\mathrm{K}_{\text {ATP }}$ channel directly whereas glucose and KIC must first be metabolised. Inhibition was fully reversible on removal of the secretagogue. In contrast to wild-type beta cells, $20 \mathrm{mmol} / \mathrm{l}$ glucose had little effect on the whole-cell $\mathrm{K}_{\text {ATP }}$ current of homozygous (-/-) beta cells, although the response to KIC and tolbutamide were well retained (Fig. $2 \mathrm{~b}$ and 5 other cells). The mean latency for current inhibition was $40 \pm 6 \mathrm{~s} \quad(n=8)$ for $20 \mathrm{mmol} / \mathrm{l} \mathrm{KIC}$ and $17 \pm 3 \mathrm{~s}(n=9)$ for $0.5 \mathrm{mmol} / \mathrm{l} \mathrm{tol}-$ butamide, and thus was not significantly different from wild-type beta cells.
The mean relationship between glucose concentration and the inhibition of the $\mathrm{K}_{\mathrm{ATP}}$ current in neonatal beta cells is given in Fig. 3. In wild-type betacells, $\mathrm{K}_{\text {ATP }}$ currents are half-maximally inhibited at a glucose concentration $\left(\mathrm{EC}_{50}\right)$ of $3.2 \mathrm{mmol} / \mathrm{l}$ glucose and almost completely blocked ( $>95 \%$ ) by $20 \mathrm{mmol} / 1$ glucose $(n=11)$. In contrast to wild-type beta cells, $20 \mathrm{mmol} / \mathrm{l}$ glucose only inhibited the $\mathrm{K}_{\mathrm{ATP}}$ current of homozygous (-/-) beta cells by $19 \pm 6 \%$ $(n=7)$. Indeed in two of these cells, even as much as $40 \mathrm{mmol} / \mathrm{l}$ glucose caused less than $20 \%$ inhibition of the $\mathrm{K}_{\text {ATP }}$ current. The dose-response curve for heterozygous $(+/-)$ beta cells was also shifted with respect to that of wild-type beta cells, having a mean $\mathrm{EC}_{50}$ of $5.5 \mathrm{mmol} / \mathrm{l}(n=9)$. It should be noted that $1 \mathrm{mmol} / \mathrm{l}$ glucose was without effect in all genotypes.

Effect of secretagogues on $K_{A T P}$ currents of beta cells from old mice. We next examined $\mathrm{K}_{\mathrm{ATP}}$ currents in beta cells isolated from old (1.5 year) mice, using the perforated patch configuration. The $\mathrm{K}_{\mathrm{ATP}}$ current of beta cells isolated from both wild-type and heterozygous old mice was as responsive to tolbutamide as that of neonatal mice (data not shown). In both cases, however, the $\mathrm{K}_{\mathrm{ATP}}$ current was less sensitive to glucose (Fig. 4). The mean $\mathrm{EC}_{50}$ was $4.7 \mathrm{mmol} / \mathrm{l}$ for wild-type beta-cells $(n=9)$ isolated from old mice compared with $3.2 \mathrm{mmol} / \mathrm{l}$ for beta cells isolated from neonatal animals. Likewise, for heterozygous beta cells the mean $\mathrm{EC}_{50}$ was $9.9 \mathrm{mmmol} / \mathrm{l}(n=7)$ for old mice but $5.5 \mathrm{mmol} / \mathrm{l}$ for neonates. This decrease in the glucose sensitivity of the $\mathrm{K}_{\mathrm{ATP}}$ current was associated with an increase in the fasting blood glucose concentration, which was $7.9 \pm 0.4 \mathrm{mmol} / \mathrm{l}$ at 3 weeks and $12.0 \pm 1.3 \mathrm{mmol} / \mathrm{l}(n=6)$ at 1.5 years of age (for heterozygous mice). 

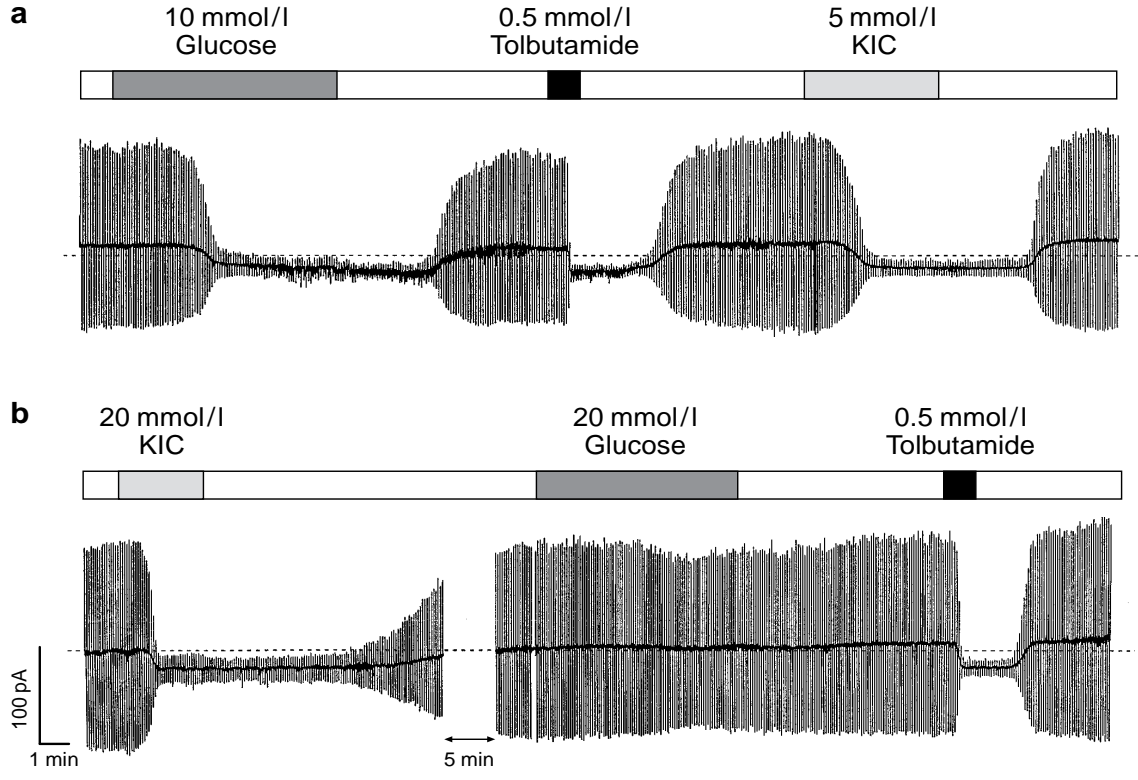

Fig. 2 a, b. Effect of KIC (20 mmol/l), glucose $(10$ or $20 \mathrm{mmol} /$ 1) and tolbutamide $(0.5 \mathrm{mmol} / \mathrm{l})$ on $\mathrm{K}_{\mathrm{ATP}}$ currents of a neonatal wild-type (a) or homozygous (-/-) beta cell (b). Currents were recorded in response to alternate $\pm 20 \mathrm{mV}$ voltage steps from a holding potential of $-70 \mathrm{mV}$ using the perforated patch configuration. The control solution (indicated by the white bar) was glucose-free. The results are representative of ten (a) or eight (b) experiments
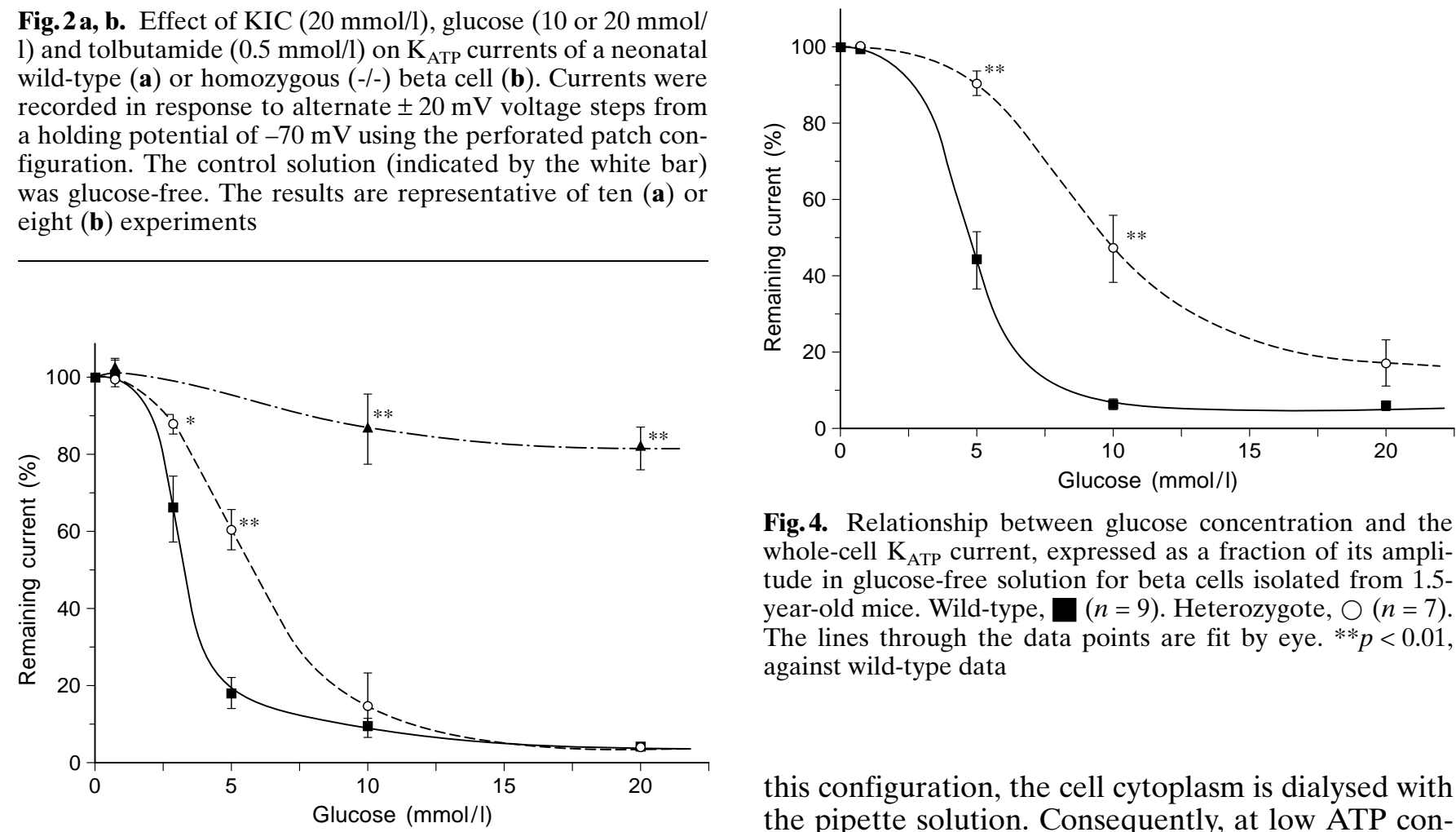

Fig. 4. Relationship between glucose concentration and the whole-cell $\mathrm{K}_{\mathrm{ATP}}$ current, expressed as a fraction of its amplitude in glucose-free solution for beta cells isolated from 1.5year-old mice. Wild-type, $\square(n=9)$. Heterozygote, $\bigcirc(n=7)$. The lines through the data points are fit by eye. $* * p<0.01$, against wild-type data

Fig.3. Relationship between glucose concentration and the whole-cell $\mathrm{K}_{\mathrm{ATP}}$ current, expressed as a fraction of its amplitude in glucose-free solution for neonatal beta cells. Wildtype, $\square(n=11)$; heterozygous $\bigcirc(+/-),(n=8)$; homozygous $(-/-), \boldsymbol{\Delta},(n=11)$. The lines through the data points are fit by eye. $* p<0.05, * * p<0.01$ against wild-type data

Whole-cell $K_{A T P}$ currents. In an attempt to evaluate whether $\mathrm{K}_{\mathrm{ATP}}$ channel expression was influenced by the presence of glucokinase, we measured the maximum $\mathrm{K}_{\text {ATP }}$ current in beta cells from different genotypes using the standard whole-cell configuration. In

this configuration, the cell cytoplasm is dialysed with the pipette solution. Consequently, at low ATP concentrations the $\mathrm{K}_{\mathrm{ATP}}$ currents increase with time after establishment of the whole-cell mode as cytosolic ATP washes out of the cell [16]. In general, the maximum washout current is observed with a pipette concentration of $0.3 \mathrm{mmol} / \mathrm{l}$ ATP, as at lower ATP concentrations the currents 'rundown' rapidly with time $[2,16]$. Figure 5 (centre) shows that the steadystate $\mathrm{K}_{\text {ATP }}$ washout currents of wild-type, homozygote $(-/-)$ and heterozygote beta cells were of comparable amplitude, which suggests that the density of $\mathrm{K}_{\mathrm{ATP}}$ channels in the different genotypes is similar. There was also no difference between newborn and old animals. In all cases, the currents were almost complete- 


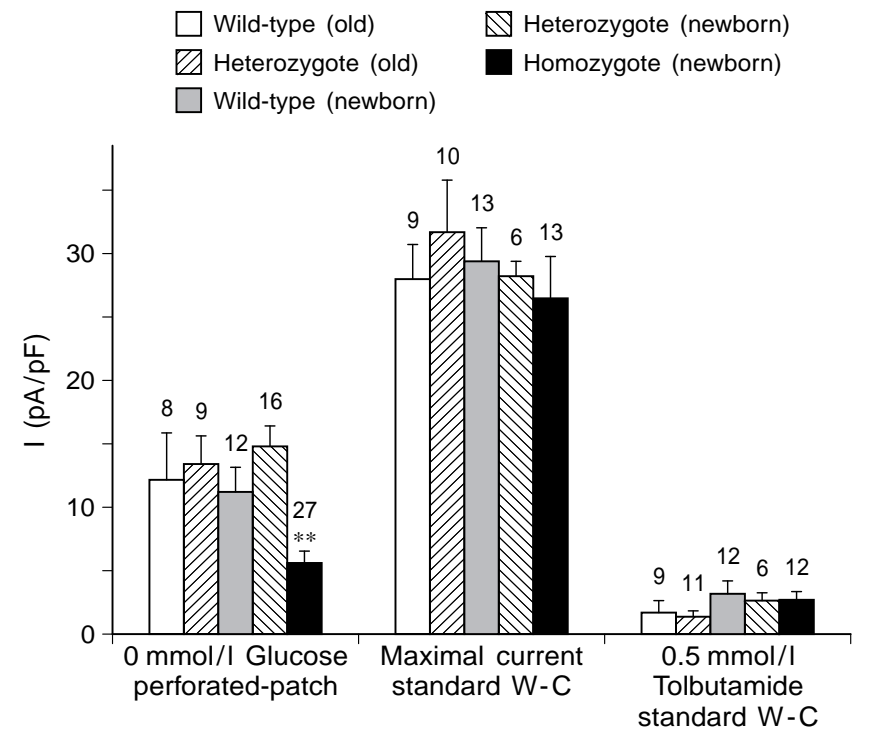

Fig.5. Histograms of $\mathrm{K}_{\mathrm{ATP}}$ current amplitudes recorded in response to a $10 \mathrm{mV}$ voltage step from a holding potential of $-70 \mathrm{mV}$ from neonatal or old beta cells. Left, perforated patch recording configuration, Centre and right, standard whole-cell (W-C) recording configuration. Wild-type beta cells (hollow bars), heterozygote beta cells (hatched bars), homozygote $(-/-)$ beta cells (solid bars). Currents are expressed relative to the cell capacitance $(\mathrm{pA} / \mathrm{pF})$ to control for differences in cell size. The numbers of cells are indicated above the bars. $* * p<0.01$ against wild-type data

ly blocked by $0.5 \mathrm{mmol} / \mathrm{l}$ tolbutamide (right), confirming that they flow through $\mathrm{K}_{\mathrm{ATP}}$ channels. Interestingly, the resting $\mathbf{K}_{\mathrm{ATP}}$ currents of intact homozygous beta cells, recorded in the absence of glucose using the perforated patch configuration, were about half the size of those found for wild-type or heterozygous beta cells. This suggests that the open probability of the $\mathrm{K}_{\mathrm{ATP}}$ channel in intact beta cells exposed to glucose-free solution is lower in homozgous mice than in wild-type or heterozygous animals.

\section{Discussion}

It is now well established that defects in the glucokinase gene are associated with impaired insulin secretion. The results we report here show that this is because glucose fails to cause $\mathrm{K}_{\mathrm{ATP}}$ channel closure and subsequent beta-cell depolarization. Consequently, activation of voltage-gated calcium channels and elevation of intracellular calcium does not occur. In contrast to glucose, the response to ketoisocaproic acid (KIC) remains unimpaired. Since KIC is metabolized entirely within the mitochondria, this result indicates that mitochondrial metabolism remains intact, even in homozygous (-/-) animals. Likewise, the sulphonylurea tolbutamide, which interacts directly with the $\mathrm{K}_{\text {ATP }}$ channel [2], is equally effective in all genotypes. The data are therefore consistent with the selective impairment of glycolysis, as a consequence of the loss (-/-) or reduction ( +/-) of glucokinase activity.

Phosphorylation of glucose to glucose-6-phosphate constitutes a rate-limiting step in glucose metabolism and is dually controlled by glucokinase and by hexokinase. Hexokinase has a low $K_{\mathrm{m}}$ for glucose $(10-100 \mu \mathrm{mol} / \mathrm{l})$ and is more than $95 \%$ inhibited by glucose- 6 phosphate at physiological glucose concentrations [3]. Glucokinase has a high $K_{\mathrm{m}}(\sim 12 \mathrm{mmol} /$ 1) and is not inhibited by glucose-6-phosphate over the physiological glucose concentration range [3]. Thus, glucokinase is believed to be the principal regulator of glucose metabolism in beta cells and to serve as the 'glucose sensor' [3,4]. Several investigators have considered whether hexokinase might play some role in insulin secretion when glucose levels are low. The fact we observed that $\mathrm{K}_{\text {ATP }}$ currents have the same amplitude in $0 \mathrm{mmol} / \mathrm{l}$ glucose and $1 \mathrm{mmol} / \mathrm{l}$ glucose in all genotypes indicates that hexokinase activity does not affect $\mathrm{K}_{\text {ATP }}$ channel activity and is thus unlikely to play a role in glucose-dependent insulin release. However, this does not necessarily mean that hexokinase is not present in beta cells, nor does it exclude the possibility that it has some other functional role, since it is possible that changes in nucleotide concentration produced by hexokinase activity are too small to influence $\mathrm{K}_{\mathrm{ATP}}$ channel activity. Indeed, the ability of homozygous beta cells to survive in tissue culture for as long as wild-type and heterozygous beta cells might be taken to indicate that hexokinase activity in homozygote beta cells is able to supply sufficient energy for survival. Alternatively, energy sources other than glucose may be used by homozygous beta cells, such as amino acids and lipids.

It is unclear why glucose has some, albeit small, effect on $\mathrm{K}_{\mathrm{ATP}}$ currents in homozygote beta cells at high concentrations. One possibility, however, is that a small amount of the liver-type of glucokinase may be induced in these beta cells. The glucokinase gene has two isoforms, one of which is expressed in the beta cell and the other in the liver [8]. These isoforms differ only in their first exons (exon 1L in the liver and exon $1 \beta$ in beta cells). In the glucokinase knockout mouse described here, the expression of the glucokinase gene in the beta cell was selectively destroyed by inactivating exon $1 \beta$, while the liver isoform remains unaffected [12]. Low expression of the liver isoform in beta cells is therefore a possibility and could explain our results.

Mutations in the human glucokinase gene cause a form of non-insulin dependent diabetes mellitus (MODY2) characterised by fasting plasma glucose levels of around $7 \mathrm{mmol} / \mathrm{l}$ which presents from childhood [6]. All patients are heterozygous for the mutation. Homozygotes have not been reported presumably because they are very rare and would be likely to die within a few days of birth, as is the case for the homozygous (-/-) mouse. Our results suggest that the 
lower insulin secretory response to glucose found in MODY2 patients may result from defective regulation of $\mathrm{K}_{\mathrm{ATP}}$ channel activity, as is the case in + /mice. They also suggest that MODY2 patients will have a normal secretory response to amino acids.

In this study, we also showed that sensitivity of the $\mathrm{K}_{\text {ATP }}$ current to the inhibitory effects of glucose is lower in old mice than in neonatal mice, whether of wild-type or heterozygous genotype. This was associated with an increase in the fasting blood glucose concentration. It is not known whether a similar increase in the blood glucose concentration occurs with age in MODY2 patients, who are the human equivalent of the heterozygous knock-out mice. However, our results suggest that this may be the case and that MODY2 patients should be carefully followed. Finally, it is well known that frequency of Type II (non-insulin-dependent) diabetes mellitus increases with age. Our data raise the possibility that some defect in glucose metabolism may be responsible for this enhanced susceptibility to diabetes with age.

Acknowledgements. We thank Dr Hiroshi Susuki and Stephen Laird for maintaining the mouse colonies. We thank the Wellcome Trust and the British Diabetic Association for support.

\section{References}

1. Ashcroft FM, Ashcroft SJH (1980) Glucoreceptor mechanisms and the control of insulin release and biosynthesis. Diabetologia 8: 5-15

2. Ashcroft FM, Rorsman P (1989) Electrophysiology of the pancreatic beta-cell. Prog Biophys Mol Biol 54: 87-143

3. Randle PJ (1993) Glucokinase and candidate gene for Type 2 (non-insulin-dependent) diabetes mellitus. Diabetologia 36: 269-275

4. Matschinsky FM (1995) Banting Lecture 1995; A lesson in metabolic regulation inspired by the glucokinase glucose sensor paradigm. Diabetes 45: 223-241
5. Froguel P, Vaxillaire M, Sun F et al. (1992) Close linkage of glucokinase locus on chromosome $7 \mathrm{p}$ to early-onset non-insulin-dependent diabetes mellitus. Nature 356: 162-164

6. Velho G, Blanche H, Vaxillaire M et al. (1997) Identification of 14 new glucokinase mutations and description of the clinical profile of 42 MODY-2 families. Diabetologia 40: 217-224

7. Hattersley AT, Turner RC, Permutt MS et al. (1992) Lancet 339: 1307-1310

8. Magnuson MA, Shelton KD (1989) An alternative promoter in the glucokinase gene is active in the pancreatic $\beta$-cell. J Biol Chem 264: 15936-15942

9. Sakura H, Eto K, Kadowaki H et al. (1992) Structure of human glucokinase gene and identification of a missense mutation in a Japanese patient with early-onset non-insulindependent diabetes mellitus. J Clin Endocrinol Metab 75: $1571-1573$

10. Sakura H, Kawamori R, Kubota M et al. (1993) Glucokinase gene mutation and impaired glucose uptake by liver. Lancet 341: 1532-1533

11. Velho G, Peterson KF, Petersenm KF et al. (1996) Impaired hepatic glycogen synthesis in glucokinase-deficient (MODY-2) subjects. J Clin Invest 98: 1755-1761

12. Terauchi Y, Sakura H, Yasuda K, Iwamoto K et al. (1995) Analysis of the pancreatic $\beta$-cell in the mouse with targeted disruption of the pancreatic $\beta$-cell-specific glucokinase gene. J Biol Chem 270: 30253-30256

13. Aizawa T, Asanuma N, Terauchi Y et al. (1996) Pancreatic $\beta$-cell-specific targetted disruption of the glucokinase gene. Biochem Biophys Res Commun 229: 460-465

14. Grupe A, Hultgren B, Ryan A, Ma YH, Bauer M, Stewart TA (1995) Transgenic knockouts reveal a critical requirement for pancreatic $\beta$-cell glucokinase in maintaining glucose homeostasis. Cell 83: 69-78

15. Smith PA, Ashcroft FM, Rorsman P (1990) Simultaneous recordings of glucose dependent electrical activity and ATP-regulated $\mathrm{K}^{+}$-currents in isolated mouse pancreatic beta-cells. FEBS Lett 261: 187-190

16. Trube G, Rorsman P, OhnoShosaku T (1985) Opposite effects of tolbutamide and diazoxide on the ATP-dependent $\mathrm{K}^{+}$-channel in pancreatic $\beta$-cells. Pflügers Arch 407: 493-499 